\title{
EMPLOYMENT OF POPULATION AS A BASIC INDEX OF ECONOMIC DEVELOPMENT OF COUNTRY
}

\author{
Oleksandra LYSIUK' \\ Vinnitsa National Agrarian University, Ukraine
}

\begin{abstract}
The actual problem of modern economical theory and practice is a problem of guaranteeing of full employment. The aggravation of this problem during the economic crisis period stimulate the necessity of searching affective mechanism to overcome unemployment and development common form of labor. In the article the level of employment in 2005-2014 years, means of its increasing are investigated using recommendations of MOP, which were created especially for Ukraine. Statistical information from Ukrainian Government Statistical Agency was used some practical recommendations to stable situation of employment in the country were given. Methodology. Using the systematic approach the current state of employment rate in Ukraine was investigated and steps for development of labor market were found. Using the economic and statistical methods, the actual state of employment rate was studied. Information for the last 10 years about employment rate in Ukraine was studied. Information from web-site of Ukrainian Government Statistical Agency was used. Results. The results of the survey showed the rate of employment was rising from 2005 till 2008 years. After that this rate has been reducing till today. The reason of this employment crisis was determined and after that some practical recommendation about rising employment rate and stability situation at Ukrainian labor market were given. We recommend to develop some entrepreneurial activities in Ukraine, to develop self-employment, but there are many problems to start these activities. People, who want to start entrepreneurial activities have many problems with high level of taxes, with high level of payments to other social systems. And they can't get credit, because of high percentage and short time. Many young people can't start work without work experience. We recommend to introduce Government programs, where young people can start work with the smaller salary and get experience for developing their skills. Practical implications. We have researched the Ukrainian labor market and analyzed the statistical information about employment rate in the country. We have analyzed the reasons of unemployment and have recommended some actions about rising employment rate. Value/originality. The researching was provided for better understanding the situation at the Ukrainian labor market. After that the reasons of employment crisis were determined and the some actions for the development Ukrainian labor market were recommended.
\end{abstract}

Key words: employment, labor market, qualification, employment rate, increase, sphere of employment.

JEL Classification: J10, J11, J24

\section{Introduction}

The worldwide problems of disability, poverty, and unemployment stem out of the interaction of multiple factors including social stigma, stereotypes, lack of access to physical infrastructure, information, and enabling environments. Given this, a singular approach toward tackling these interrelated issues falls short. This article attempts to highlight the correlation of poverty, disability, and employment through the linkages with education, accessibility, legislative and policy changes, and awareness. It draws on the experiences of the National Centre for Promotion of Employment for Disabled People (NCPEDP) to propose a course of action which is built on a strong cross-disability rights- based movements driving a multi-pronged, multisectorial approach toward addressing inequalities to break the cycle of poverty and disability.

The ratio is used to evaluate the ability of the economy to create jobs and therefore is used in conjunction with the unemployment rate for a general evaluation of the labor market stance. Having a high ratio means that an important proportion of the population in working age is employed, which in general will have positive effects on the GDP per capita. Nevertheless, the ratio does not give an indication of working conditions, number of hours worked per person, earnings or the size of the black market. Therefore, the analysis of the labor market must be done in conjunction with other statistics (Kolot, 2010).

\footnotetext{
Corresponding author

${ }^{1}$ Department of Agrarian Management, Vinnitsa National Agrarian University.

E-mail: lysiukaleksandra@gmail.com
} 


\section{Forming components of the labor market}

The employment of population is provided by Government through active social economy policy to satisfy their needs of choosing activities and stimulation new working places and entrepreneurial development. The most important indicator of economy growth is employment. Many economists determine this word differently, but everybody say, that these are people, who bring them income in money or other forms.

Active Government policy of employment provides the developing programs of employment promotion. These programs take some groups of people: young people, women, disable's and other specific groups. In developing countries most programs of employment concern some categories of people, who need help and support.

The goal of Government and Regional employment programs (short time and longtime) is promotion of employment rate and needs of citizen in the work.

But there are some problems on the Ukrainian labor market:

- most of employee are considered in agricultural (near 5 million), where payment is not high;

- innovative development is not used by all capacity and not qualified work is more popular;

- every 5th person works not according to his/her education;

- many people work abroad, because they can't find a good job with good payment in Ukraine (Zhukovski, 2013).

\section{Regulation of labor market in Ukraine}

For the better situation in employee market, the labor market must be regulated and formulated more dynamically.

Law declared principles of state policy of Ukraine concerning the regulation of employment:

- ensuring equal opportunities for all citizens in exercising their right to free choice of activities according to abilities and training based on personal interests and social needs;

- coordination of employment in other areas of economic and social policies based on national and regional employment programs;

- cooperation of trade unions, associations, enterprises, institutions, organizations or their authorized bodies in cooperation with the state administration in the development, implementation and monitoring of measures to ensure employment.

The mechanism of regulation of employment includes the following components: development of national and regional employment programs; organization and support, functioning state employment; the participation of enterprises, institutions and organizations in the implementation of the state policy of employment; functioning of the State Employment Fund; vocational training, advanced training and retraining of unemployed citizens; providing compensation to citizens who lost their jobs or are retraining; control of public authorities for compliance with the legislation of Ukraine on employment.

In solving many problems of employment and unemployment important functions assigned to the State Employment Service. Its activity is led by the Ministry of Labour and Social Policy of Ukraine and local administrations. It is funded by the State Fund for Employment and exempt from taxes, customs and other charges made to the budget.

According to the law, the State Employment Service analyzes and forecasts the supply and demand for labor, inform the public and public authorities on the labor market; consults citizens, business owners and institutions about the possibility of providing and labor requirements for trades and other issues that are useful to promote employment; provides accounting vacancies and individuals who apply for employment; assists citizens in the selection of relevant work, and the owners - in the selection of appropriate personnel; organizes the necessary training and retraining of public employment service system and other institutions; registers the unemployed and assist them, including cash; participates in preparing prospective and current employment programs and measures for social protection of different groups of unemployment (Lycholat, 2007).

\section{Analyze of economy-active population rate}

Labor market like any other market depends on the prevailing situation in the environment. An important factor in it was the economic crisis in the country. However, it is not only the cause of the current state of the labor market, but also not resolved domestic problems that occur in the economy of our country:

1. Unreliability and concealment of information about the true state of the labor market and its prospective opportunities.

2. The absence of industrial employment dynamics.

3. Low productivity, whichleads to inconsistencies wages. In Ukraine, the Ukrainian labor productivity is $40 \%$ lower than in Central and Eastern Europe. The current problems of wages are constantly in sight of the government. Trying to solve these problems, especially for poor sections of the population, the government increases the minimum wage and salaries of low-paid categories of staff. Automatically increase in wages occurs in other workers, leading to a number of negative consequences in the public sector reduced premiums, copayments removed, workers are sent on unpaid vacations, transferred to a shorter working week, spend reduction; the private sector - diminishing returns fewer deductions to the budget, delaying the payment of salaries. Also among the several reasons for the decline in real wages in the Ukrainian society is that every 13 working in Ukraine has reached retirement age, their productivity is low.

4. Another problem of Ukraine is the uneven distribution of human resources in the territory of the state - the main concentration characteristic of eastern regions (more than a third of the working population); the largest migration 
gain characteristic is in Kyiv; the largest outflow comes from Chernivtsi, Ivano-Frankivsk, Cherkasy and Kyiv regions; surplus labor characteristic of Dnipropetrovsk, Donetsk and Kharkiv regions; long-term unemployment enveloped the Zhytomyr, Ivano-Frankivsk, Rivne, Ternopil region.

5. Ukrainian scientists identify the most important problem of the market - the deformation in the sectoral structure and professional qualification warehouse. The reason for the low level of skills can be called financial motivation, limited employment opportunities, lack of guarantees stability of industrial activity in the specialty, structure mismatch promising professional education needs of the labor market and professional qualification level structure. Accordingly, there is a staff shortage for those industries that barred the use of technical and technological innovations.

However, for the appearance, formation and functioning of the labor market requires certain conditions. First of all, should be provided with legal conditions for the functioning of the market, including the possibility of free movement for its citizens free choice of employment, ie a legal worker freedom, the ability to dispose of its ability to work. But this is not enough because, in economic terms, the owner of labor had to sell it when it does not have all the necessary for the conduct of its economy as a source of livelihood for reception or when income from other sources is insufficient.

For a more detailed snapshot of the economically active population was investigated State Statistics Committee of Ukraine for the last 10 years, which will give us an idea of the general state of the labor market in Ukraine.

Table 1

Economically active population Ukraine

\begin{tabular}{|c|c|c|c|c|}
\hline & \multicolumn{2}{|c|}{$15-70$ y.o } & \multicolumn{2}{c|}{ people of working age } \\
\hline & $\begin{array}{c}\text { the } \\
\text { average, } \\
\text { thsd. } \\
\text { the \% of the } \\
\text { population } \\
\text { in the } \\
\text { corresponding } \\
\text { age group }\end{array}$ & $\begin{array}{c}\text { the } \\
\text { average, } \\
\text { thsd. }\end{array}$ & $\begin{array}{c}\text { the } \% \text { of the } \\
\text { population } \\
\text { in the } \\
\text { corresponding } \\
\text { age group }\end{array}$ \\
\hline 2005 & 20280,8 & 62,0 & 20582,5 & 71,1 \\
\hline 2006 & 22245,4 & 62,2 & 20481,7 & 70,9 \\
\hline 2007 & 22322,3 & 62,2 & 20545,9 & 71,2 \\
\hline 2008 & 22397,4 & 62,6 & 20606,2 & 71,7 \\
\hline 2009 & 22150,3 & 63,3 & 20675,7 & 72,3 \\
\hline 2010 & 22051,6 & 63,3 & 20321,6 & 71,6 \\
\hline 2011 & 22056,9 & 63,7 & 20220,7 & 72,0 \\
\hline 2012 & 22011,5 & 64,3 & 20247,9 & 72,7 \\
\hline 2013 & 21980,6 & 64,6 & 20393,5 & 73,0 \\
\hline 2014 & 21767,3 & 65,00 & 20478,2 & 73,1 \\
\hline
\end{tabular}

The table 1 can be concluded by 2008, including the number of economically active population increased by 116.6 thousand people in comparison with 2005. The economic downturn since 2009, albeit gradual, created conditions for increasing income, primarily wages and reduce its share in total revenues. However, due to low standards of overall pay income remains low. The low level of labor income and their unjustified differentiation inevitably leads to a crisis of motivation of work. The result is low labor activity, incomplete use of labor capacity, reducing the role of labor. Everything is added and the high tax burden that discourages neither employers nor, in fact, the most labor.

Quite remain sharp inter-relationship and levels of remuneration. Belonging to a particular field of activity creates value in pay. In fact, the payment should depend on the quality and results of work, as the world practice. According to the specific regional economy systems, stored and high regional differences in the level of wages. Already amplitude is $100 \%$ of the national average level in some areas.

According to the State Statistics Committee of Ukraine, the average monthly nominal wage full-time employee during the first quarter of 2008 amounted to 1619 UAH. And increased in comparison with the same period last year to $39.4 \%$. The growth of real wages (over 14\%) was observed in all regions except the Dnipropetrovsk region and the largest - in Volyn, Zakarpattia, Kirovohrad, Kyiv am Chernihiv regions.

However, the current state of the labor market is characterized by a number of problems which is a barrier to normal social and economic development of the country as a whole and its individual regions. There is a problem economic activity, quantitative and qualitative imbalance between supply and demand in labor, low qualification level of jobseekers and the working population and employment problems of young people and the disabled, especially in the self-governing cities, mining regions, rural areas, illegal foreign labor Migration mal internal labor migration and informal labor sector.

The reasons employers unmet demand for labor by graduates of vocational schools are:

- the poor quality of training (graduate denied the workplace on the basis of low-skilled, non professional knowledge and skills needs of the workplace, which is a consequence of imperfect because of the content of professional training qualification characteristics trades outdated and no independent qualification attestation graduates);

- preparation of educational institutions of skilled workers, professional composition which ignores the situation on regional labor markets (due to lack of state vocational orientation population and imperfect low effective system of state order for training personnel for functioning administrative basis)

- the basis of reasons employers unmet demand for quality manpower by adults - lack of adult education for working life. The burden of financing vocational training in producing placed only on the employer. The result is the inability to raise the economic level of qualification of workers or employers are not interested in improving the quality of staff.

At the same time, and there are problems in this segment of the labor market. The effectiveness of private farms is low, difficult labor, social security - insufficient.

Another problem of the labor market in Ukraine is toning employment. The problems of illegal employment relations in the areas related to: 
- a significant level of financial burden on the payroll;

- failure to comply with labor laws regarding proper registration of employment by the employer;

- not regulated internal migration, the main factors which the imbalance of demand and supply of labor in the regions (currently the largest number of vacancies offered by employers Kyiv, Dnipropetrovsk, Donetsk, Kharkiv, Zaporizhia region).

The problem is illegal work of citizens of Ukraine abroad, inadequate social protection, risk insurance and pension savings, the lack of reliable mechanisms to transfer the received funds for work abroad, returning migrants. Leveling the negative effects of labor migration from Ukraine, first of all connected with the creation of attractive domestic labor market, the conclusion of agreements on employment and social security of citizens of Ukraine who are abroad.

A characteristic feature of Ukraine's labor market is the low level of employment of people with disabilities. According to the Information Centre of the Ministry of Labor in 2014, the number of disabled workers was 515 thousand. People or $39 \%$ of the total number of disabled people of working age, while in other countries the employment rate of this category of citizens is considerably higher (for example, in Italy - 55\% in Sweden - 60.1\%, in China - almost 80\%)

The main reasons that hinder the employment of disabled people in Ukraine are:

- a relatively low level of education of disabled persons and their training;

- lack of support for those first entering the labor market (graduates);

- lack of jobs, which may be involved labor disabled (Tymosh, 2013).

\section{Conclusions}

In order to overcome regional imbalances in the labor market and economic development, it is advisable to introduce the following system events:

- introduction of employment by creating new jobs through the establishment of a favorable investment regime for businesses which create new jobs, providing state support to agricultural producers, businesses in depressed regions; - improving the mechanism of formation, placement and execution of the state order for training, research and pedagogical skilled workers based on the state of regional labor markets;

- introduction of system of interaction of employers and vocational institutions by enhancing the participation of employers in creating a modern educational-production base

- development and implementation of programs to improve the demographic situation in the region by providing financial support to the most vulnerable sections of the population; decent social guarantees to large families (installation benefits in health, education service)

- implementation arrangements for the employment of graduates, the Law of Ukraine "On Ensuring young people who received higher education or vocational education first job of providing subsidies to employers."
In our view, indeed most essential lever for employment policy is to regulate the demand for labor, which, as is known, can be individual and aggregate. Indyvidualnyy demand (demand separate employer) depends on the following factors:

- demand for products firm, as an employer, you need a workforce primarily as a resource for production of new goods and services. The demand for labor, in other words, is a derivative product demand firm;

- of production (capital efficiency and size, features technologies, methods of organization of production perfection labor i);

Since, as noted, the demand for labor is a derivative of demand for product firm (which in a competitive market depends on prices), we can conclude that he is also a derivative volume production and the general fund wages, which is in disposal of the employer. The higher the total salary fund size, the more workers can be hired by the employer to hire. I on the contrary, the higher the average salary of one worker, the less number of them will be recruited.

The labor market in Ukraine in modern conditions determined by the general state of the economy, namely the recession, structural setbacks, changes in the forms of property, the situation in the invest field. Consequently, the demand for labor is also a state of crisis, so the economy of Ukraine in modern terms is characteristic of the simultaneous stimulation of demand for labor i reduce its proposal.

On the one hand, in Ukraine in terms of the emergence of a large quantity of temporarily unemployed workers, who are mostly exempted from productive sectors due to restructuring of the economy, liquidation of unprofitable enterprises, expansion of private property, there is a need demand for labor. The latter involves the stimulation of job places i development of productive forces, straight lines investments in the creation and reconstruction work places, creating temporary work places, setting privileges taxation and loans for various i regions where it is desirable to enlarge the demand for labor, i t. N. In addition that, in our opinion, stimulate the demand for labor may contribute to the following actions:

- liquidation of legal restrictions of employment growth (to allow the participants to clarify employment contract schedule of working hours, providing opportunities individual Guest regulation of working time, liquidation of restrictions on the number of employed workers);

- indemnity costs to the enterprise caused by search training i hiring workers;

- assistance in enterprise of supplying of material resources, guaranteeing sales of products it. n. an enterprise of the increase provided work places;

The enterprise benefits straight lines for each hired worker; - creating conditions for economic interest of enterprises in ensuring Employment disabled, youth and other groups, less competitive market labor (installation privileges on payments in the budget of the workforce of these groups grants to create specialized work places and organization of vocational training i t. n. ) 
- creating conditions for widespread use of elements of flexible labor market, including strengthening strengths labor costs, labor mobile professional and territorial the use of flexible forms of employment.

The same basic direction of increasing the demand for labor was and still improving socio-economic structure of the economy (establishment of various forms of ownership), which is based on privatization, whose function is to create potentially Investors. Along with the improvement of organizational and economic structure of the economy, improving the socio-economic structure will help create market-competitive environment in Ukraine.

Implementation of these measures will improve the quality of the national workforce to overcome regional disparities in the labor market in Ukraine and significantly increase the demand for labor

\section{References}

Annual statistical of Ukraine till 2014 . - Kyiv, Consultant, 370 p.

Kolot, A.M. (2010). Evolution of state employment policy in the countries with developed market economies. Employment and labor market. - Vol. 11, p. 47-55.

Lycholat, S.M. (2007). Employment of population as a basic index of economic development of country. Scientific herald, - Vol. 17, issue 8, p. 275-279.

Tymosh, I.M. (2013). Labor economics. - Ternopil, Aston, 169 p.

Zaytseva, K.V. \& Fanadina, O.S. (2008). Socialization problems and peculiarities of the labor market in Ukraine. Economic space, - Vol. 1, p. 200-205.

Zhukovski, M.O. (2013). Human resources as a part of enterprise competitiveness. Actual economy problems, Vol. 2, issue 68, p. 54-59.

\section{Александра ЛЫСЮК}

\section{ЗАНЯТОСТЬ НАСЕЛЕНИЯ КАК ОСНОВНОЙ ПОКАЗАТЕЛЬ ЭКОНОМИЧЕСКОГО РАЗВИТИЯ СТРАНЫ}

Аннотация. Актуальными проблемами современной экономической теории и практики есть проблема трудоустройства граждан. Обострение данной проблемы в условиях экономического кризиса вызывает необходимость поиска эффективного механизма преодоления безработицы и таким образом дальнейшего развития общественной формы труда. В статье исследовано уровень занятости населения 2005-2014 гг, способы его повышения с помощью рекомендации МОП, которые специально созданы для Украины. Была исследована статистическая информация Госкомстата Украины, на основе чего были разработаны некоторые практические рекомендации по становлению и развитию уровня занятости страны. Методология. Исследовано состояние рынка труда с помощью системного подхода, а также предложено ряд мероприятий по его развитию. Исследовано состояние занятости населения по отраслевой классификации, при этом было использовано экономико-статистические методы. Мы исследовали информацию об уровне трудоустройства за последние 10 лет в Украине за данными Госкомстата Украины. Информация была взята с официального веб-сайта Госкомстата Украины. Результаты исследования показали, что уровень занятости граждан имел позитивную тенденцию с 2005 по 2008 г. На протяжении следующих годов, этот уровень незначительно, но все же падает. Были исследованы причины спада занятости, на основе чего были разработаны практические рекомендации по улучшению уровня занятости и стабилизации ситуации на рынке труда Украины. Мы предлагаем развивать некоторые виды предпринимательской деятельности в Украине, в том числе само занятость, но большинство проблем встречается на пути развития данных видов деятельности. Граждане, которые начинают предпринимательскую деятельность - встречаются с такими проблемами, как высокий уровень налогообложения и других специальных отчислений. Также при кредитовании бизнеса, присутствуют высокие проценты по использованию кредитных средств. Также много молодых специалистов не могут начать свою трудовую деятельность при отсутствии определенного трудового опыта. Мы разработали некоторые предложения по трудоустройству и обучению молодых специалистов, при условии минимальной заработной платы и развитию их способностей. Практическое значение. Исследовав уровень занятости в Украине, мы проанализировали причины безработицы и разработали некоторые рекомендации по повышению уровня занятости. Значение/оригинальность. Исследование было проведено для более четкого понятия состояния рынка труда Украины. На основе этого были выделены некоторые причины кризиса рынка труда и разработаны рекомендации по улучшению уровня занятости в Украине. Большое значение имеет возможность развития предпринимательской деятельности, при которой индивидуумы самостоятельно выбираю род своей деятельности и программы разработки собственного трудоустройства. Были предложены Государственные и региональные программы по развитию уровня занятости, а также предложены идеи по обеспечению рабочими местами молодых специалистов по окончанию учебного заведения, которые не имеют опыта работы. 